\title{
Waldemar Kmiecikowski, Istnienie. Człowiek. Moralność. Studia z dwudziestowiecznej filozofii polskiej, Oficyna Wydawnicza Fundacji Fuhrmanna, Chojnice 2017, ss. 411
}

DOI: http://dx.doi.org/10.12775/RF.2017.040

Waldemar Kmiecikowski w swojej najnowszej książce zaprasza czytelnika do odbycia intelektualnej podróży szlakiem, który on sam pokonywał przez wiele lat swojej pracy naukowej. Naturalną więc rzeczą jest to, że prezentuje w niej różne obszary badań i różnorodność punktów widzenia. Czytelnik oczekujący zatem wszechstronnego omówienia jednego zagadnienia bądź dążący do poznania całości badań danego filozofa może być rozczarowany. Sam autor stwierdza, że "Istnienie. Człowiek. Moralność. Studia z dwudziestowiecznej filozofii polskiej" jest publikacja, która obejmuje rozprawy i recenzje powstałe na przestrzeni kilkunastu lat (s. 9). Wspomnianego wyżej rozczarowania jednak nie dozna czytelnik, który będzie dążył do poszerzenia swej wiedzy o polskiej filozofii XX wieku i skorzysta z możliwości zapoznania się z 17 artykułami i 7 recenzjami, które powstawały pierwotnie jako autonomiczne teksty naukowe (i jako takie publikowane były już wcześniej), a które w większości zostały poddane pewnym modyfikacjom (s. 410) i które przez Waldemara Kmiecikowskiego zostały scalone w cztery spójne tematycznie całości. Ów podział zresztą stanowi zasadniczy pryzmat interpretacyjny, przez który można spoglądać na zawartość poszczególnych komponentów książki.

\section{Co to znaczy istnieć?}

Na początku XVIII wieku Gottfried Wilhelm Leibniz w małej rozprawce zatytułowanej Principes de la naturę et de la grace fondés en raison postawił słynne pytanie: Dlaczego istnieje raczej coś niż nic? Pytanie to było konsekwencją domagania się przez Leibniza dla wszystkiego racji dostatecznej. Uważał, że wszystko, co istnieje, musi mieć swoje uzasadnienie. Tym samym bez uzasadnienia może być tylko NIC. Ale czy o NICZYM możemy mówić, że istnieje? Stąd rodzi się pytanie o naturę istnienia. 
Nurtuje ono również Waldemara Kmiecikowskiego, który pierwszą część swojej książki zatytułował Uchwycić istnienie. Wokót ontologii i metafizyki. Odnaleźć w niej można wszechstronną prezentację problemu istnienia, które stanowiło istotny przedmiot badań Romana Ingardena, Stanisława Ignacego Witkiewicza (Witkacego), a także Michała Hellera. Autor rekonstruuje poszczególne komponenty ich refleksji egzystencjalnej. Analizy prowadzone przez Waldemara Kmiecikowskiego pokazują odmienność spojrzenia na istnienie każdego z wymienionych filozofów (na co wpływa odmienność ich paradygmatów filozoficznych), a także wieloaspektowość i bogactwo problematyki istnienia, która odsłania się $\mathrm{w}$ ramach ich rozważań. Zupełnie inna jest przecież perspektywa ujmująca kwestię istnienia $\mathrm{w}$ pryzmacie fenomenologii Romana Ingardena, a inna w przypadku biologizmu monadycznego Witkacego czy w ramach Hellerowskich filiacji filozofii i fizyki teoretycznej. Poznając zawartość części pierwszej, zyskuje się możliwość towarzyszenia Waldemarowi Kmiecikowskiemu w jego badaniach koncentrujących się na istnieniu ujmowanym $w$ horyzoncie ontologii ( $w$ Ingardenowskim rozumieniu jako analizie zawartości idei), w szacie metafizycznej konkretności bytowej czy w perspektywie matematycznej racjonalności istniejącego Wszechświata.

Bogactwo zagadnień związanych z istnieniem - ściśle zresztą skorelowanych z odmiennością naczelnych założeń filozoficznych Ingardena, Witkacego i Hellera - znajduje wyraz w badaniach Kmiecikowskiego. Autor bowiem wprowadza m.in. w zawiłości związane z Ingardenowską polemiką z Edmundem Husserlem (eksponując zdecydowanie odrębność obu wariantów filozofii fenomenologicznej), statusem istnienia idealnego, intencjonalnego, realnego czy absolutnego (które w perspektywie badań Romana Ingardena różnią się między sobą) i w przestrzeń charakterystycznej dla Witkacego metafizycznej terminologii (np. Istnienia Poszczególnego, cielesnych monad, Prawdy Absolutnej) i jego filozoficznych skrótów (AR, MM, BDŚ, IP etc.). To tutaj pojawia się także okazja do poznania - jakże odmiennej od wymienionych wyżej - perspektywy Hellera, w której dominuje refleksja kosmologiczna (z progiem Plancka, geometrią nieprzemienna, nielokalnościa, paradoksem horyzontu czy nieprzemiennym początkiem) prowokująca do wyjaśnienia podatności istniejącego Wszechświata dla opisu matematycznego i uzasadniająca twierdzenie Kmiecikowskiego, że wnikając w subtelności modeli kosmologicznych - w pewnym sensie - zblizalibyśmy się do urealnionej, skonkretyzowanej na poziomie bytu Wszechświata aktywności Bożego umystu (s. 162). Część pierwsza książki okazuje się więc wielością pryzmatów filozoficznych, przez które autor tomu spogląda na istnienie. Jego oblicze zaś różnicuje się w zależności od siatki pojęciowej wnoszonej przez owe pryzmaty (ontologicznej, metafizycznej i kosmologicznej). 


\section{Trzcina myśląca}

Blaise Pascal stwierdził, że człowiek jest trzcina najsłabsza na wietrze, najwatlejsza w przyrodzie, ale trzcina myślacą. Zdanie to dobrze oddaje fenomen człowieka, który z biologicznego punktu widzenia nie ma wielu predyspozycji, by zajmować uprzywilejowane miejsce w otaczającym go świecie. Jednak właśnie świadomość tego czyni go kimś wyjątkowym. Zagadnienie to intrygowało wielu myślicieli. Zainspirowało też do osobistych poszukiwań Waldemara Kmiecikowskiego. Owoce tych poszukiwań znajdziemy w drugiej części jego książki zatytułowanej Natura $i$ istota człowieka. Poszukiwania antropologiczne. Poprzez taki tytuł autor unifikuje sześć kolejnych artykułów. Są one skoncentrowane na problematyce człowieka, ale jednocześnie kontynuują obecne w poprzedniej części pewne napięcie między ontologią ukierunkowaną na precyzyjne badanie zawartości idei (istniejących idealnie i ogólnie) a metafizyką ukierunkowaną na byt faktycznie istniejący. Czytelnik zyskuje możliwość kolejnego wglądu w owo zróżnicowanie, które przeniesione zostaje na grunt antropologiczny, a znajduje zasadniczy wyraz w odrębności koncepcji Romana Ingardena (w jej komponencie ontologicznym) i Stanisława Ignacego Witkiewicza - obraz człowieka obu ujęć jawi się jako fundamentalnie odmienny.

W horyzoncie ontologii Romana Ingardena człowiek okazuje się bytem opisywanym przez takie kategorie, jak przedmiot trwający w czasie, natura konstytutywna, monada, strumień świadomości, dusza czy podmiot. Badania Waldemara Kmiecikowskiego wszechstronnie rekonstruują skomplikowany i zróżnicowany kontekst, w którym Ingarden osadza człowieka. To tłumaczy obecność momentów bytowych zawartych w poszczególnych typach istnienia (zwłaszcza aktualności i szczelinowości istnienia), ontologii dzieła literackiego (z odróżnieniem przedmiotu artystycznego od przedmiotu estetycznego), czy idealnych idei wartości moralnych i estetycznych (idealnej sfery aksjologicznej). Wyraźnie należy dodać, że - co czytelnie eksponuje autor monografii - koncepcja antropologiczna Ingardena obejmuje nie tylko część ontologiczna, lecz i część, w której człowiek rozważany jest jako osoba faktycznie istniejąca (perspektywa bliższa ujęciu metafizycznemu). Taki człowiek to osoba, która doświadcza obecności czasu (jako czegoś destrukcyjnego, ale i częściowo uległego wobec świadomości - wówczas osoba może przezwyciężać czas - s. 212) i staje się w pełni bytem osobowym poprzez przylgnięcie do piękna i dobra (s. 221). Koncepcja człowieka Ingardena zostaje przez autora dyskutowana wszechstronnie i obejmie również problem relacji faktycznie istniejącego człowieka do Boga. Ciekawym rozwiązaniem Waldemara Kmiecikowskiego jest zestawienie rozprawy Ingardenowska koncepcja czasu i osoby droga do nieobecnego Boga i Pomiędzy Absolutem możliwym a rzeczywistym. Filozofia Romana Ingardena jako poszukiwanie Boga. 
Ostatni artykuł powstał dziesięć lat później od poprzedniego, co związane jest z pewną modyfikacją akcentów dotyczących miejsca Boga w filozofii Romana Ingardena, a czego szczególnym wyrazem jest twierdzenie kończące ten tekst: dzisiaj nieco wytonowałbym moją ówczesna wypowiedź (s. 246).

Radykalnie odmienną koncepcję antropologiczną zaprezentował Witkacy, według którego człowiek jest przede wszystkim istotą cielesną i bezpośrednio poznaje własne ciało. Owo ciało może być wprawdzie poznawane $\mathrm{w}$ spojrzeniu zewnętrznym (podobnie jak i inne byty świata zewnętrznego), ale najważniejsze jest doświadczanie własnego ciała niejako od środka - wewnętrzne czucie swojego ciała. Autor monografii pisze, że nieustannie "dotykam" siebie od wewnatrz; "dotykam" własnego ciała [...]. Pierwotne nie jest doświadczanie świata zewnętrznego, lecz właśnie wewnętrzne, świadome (!) dotykanie własnego ciała (263). To dzięki dotykowi wewnętrznemu człowiek jako Istnienie Poszczególne (IP) wie o swoim istnieniu, co jest możliwe dzięki temu, że Witkacy przypisuje świadomości (jaźni) cielesność i rozciągłość, a co Waldemar Kmiecikowski precyzyjnie wyraża przez formułę jestem "cielesnym trwaniem" albo trwaniem "utkanym cielesnościa" (262). Człowiek jest więc cielesną monada, która składa się z wielości innych (mniejszych) Istnień Poszczególnych, z których każde zawsze jest rozciągłe i obdarzone pewną dozą czucia samego siebie. Koncepcja człowieka jako monady cielesnej jest szczególnie ważna - przecież całe Istnienie Witkacy uzna za to, które składa się z wielości żywych, cielesnych i samo-czujących się monad łączących się $\mathrm{w}$ większe całości. To tworzenie jedności $\mathrm{z}$ wielości jest doświadczane przez człowieka od środka i jest opisywane - precyzyjnie zresztą omówione przez Waldemara Kmiecikowskiego - za pomocą skomplikowanej terminologii Witkacego: trwanie samo dla siebie (AT), byt w sobie i dla siebie (BDŚ), trwanie byłe (BT), trwanie obecne, (OT), trwanie przyszłe (PT), jakości (XN) etc. Owo doświadczanie przez człowieka własnej identyczności (jedności Ja), pomimo wielości przemijających przeżyć (Witkiewiczowskich jakości), jest szczególnie ważne, a jego znaczenie wykracza poza ramy antropologii. Okazuje się przecież być znanym Witkacowskim uczuciem metafizycznym, które znajduje wyraz $\mathrm{w}$ filozofii, religii i sztuce (jego estetycznym korelatem jest Czysta Forma), a które równocześnie intensywnie przypomina o fundamentalnej samotności człowieka - uczucie metafizyczne odsłania bowiem (a w pewnym sensie także identyfikuje się z nia) grozę Istnienia (s. 283).

\author{
Być albo nie być \\ - oto jest pytanie. \\ Kto postęuje godniej: ten, kto biernie \\ stoi pod gradem zajadtych strzat losu, \\ Czy ten, kto stawia opór morzu nieszczęść \\ I w walce kładzie im kres?
}


Ten hamletowski dylemat, nie jest tylko wyrazem dramatopisarskiego kunsztu Szekspira. Szekspir jedynie nadał poetycki kształt bardzo prozaicznym dylematom moralnym, które targają człowiekiem. Stąd mówiąc o człowieczeństwie, nie sposób uciec przed zagadnieniami etycznymi. Dlatego w kolejnej części Studiów z dwudziestowiecznej filozofii polskiej Waldemar Kmiecikowski podejmuje wybrane motywy refleksji etycznej Mieczysława Alberta Krąpca, Romana Ingardena i Zygmunta Baumana. Podobnie jak we wcześniejszych rozważaniach, także i tutaj więc czytelnik motywowany jest do zapoznania się z różnorodnością poglądów ściśle związaną z odmiennością szkół filozoficznych poszczególnych myślicieli. W przypadku badań prowadzonych przez Krąpca mamy do czynienia z tomistycznym wariantem filozofii moralnej. Prawda moralna w ujęciu Mieczystawa Alberta Krapca jest interesującym i syntetycznym omówieniem koncepcji, która wyrasta z klasycznej refleksji systemowej i której nie można traktować w izolacji od naczelnych rozstrzygnięć metafizycznych. Człowiek jest przecież bytem wyjątkowym, ale zasadnicza aparatura pojęciowa tycząca bytu jako bytu ma zastosowanie także do niego. To wskutek tego w artykule pojawia się m.in. dobro, cel, dążenie, pożądanie czy relacje transcendentalne, a wszystkie te kategorie służą ostatecznemu wyjaśnieniu działania człowieka. To wyjaśnienie systemowe aktywności człowieka jest centralnym elementem badań etycznych Krąpca. Jestem uwikłany w życie moralne niejako bez mojej woli wejścia w "przestrzeń moralna". Ta ostatnia bowiem w specyficzny sposób jest zawarta we mnie - poprzez każda podjęta decyzje (s. 307). Skoro więc jak to podkreśla Waldemar Kmiecikowski - wolne i rozumne działanie człowieka skupione $\mathrm{w}$ momencie podejmowania decyzji zawsze ma wymiar moralny, to analiza decyzji identyfikuje się z analizą życia moralnego. Podjęcie decyzji o działaniu jest stworzeniem bytu moralnego, jest momentem ostatecznego wyboru, w którym człowiek przez akt woli podejmuje ostateczną decyzję o wyborze sądu praktycznego i za pomocą niego dokonuje determinacji siebie do działania; determinacji, która przybiera postać tak chcę (s. 306). Dodać należy, że wartością zaprezentowanego artykułu jest nie tylko skrupulatność w prezentacji koncepcji Krąpca (obejmującej na przykład problem synerezy, prawa naturalnego, relacji sądu teoretycznego do sądu praktycznego czy eudajmonizmu), lecz także polemika z niektórymi punktami tej koncepcji.

Jeszcze innym myślicielem podejmującym refleksję etyczna, któremu poświęcił swą uwagę autor monografii (tym razem w dwóch artykułach) jest Zygmunt Baumann. Tym razem pojawia się możliwość zapoznania się $z$ badaniami odbiegającymi zasadniczo od innych tekstów zawartych $\mathrm{w}$ pierwszych częściach tomu. O ile bowiem przemyślenia w ramach fenomenologii Romana Ingardena, monadyzmu biologicznego Witkacego, tomizmu Mieczysława Alberta Krąpca czy filozofii nauki Michała Hellera zawsze były wyrazem - jak pisze we wstępie Kmieci- 
kowski - pokornego otwarcia na logos prawdy (s. 9), o tyle Zygmunt Baumann wprowadza czytelnika w sferę niejasności i niepewności odnośnie do możliwości dotarcia do prawdy (a także jej obiektywnego statusu). Klasyczne Baumanowskie określenia typu płynne czasy, płynne życie, syndrom konsumpcyjny, mord kategorialny czy zmierzch Wieku Etyki umożliwiają opisanie kondycji współczesnego człowieka i etapów prowadzących do aktualnego jego zagubienia. Szczególnym i jedynym środkiem zaradczym ma być aktywność moralna związana z poczuciem radykalnej odpowiedzialności za każdego innego człowieka (Baumann nawiązuje tutaj do Levinasa ) i wyzwolenie tej aktywności z powszechnych i obiektywnych norm moralnych - ogołocenie kontekstu moralności z sensowności i racjonalności (s. 351). Wymienione elementy zostają omówione przez autora Istnienia [...], który jednocześnie zajmuje wobec nich zdecydowanie krytyczną postawę. Waldemar Kmiecikowski - dystansując się od socjologicznej i uwodzącej narracji Baumana - wskazuje na niespójności w rozważaniach Baumana i na ich filozoficzne źródło. Przecież (pisze autor książki): omawiany filozof w swojej bogatej spuściźnie [...] porusza się $w$ horyzoncie niestabilności ontycznej. Ta ostatnia stanowi trwały (aczkolwiek wprost przez autora nieujawniany) motyw jego rozważań. Te bowiem dokonuja się niejako w tle bytowego chaosu (s. 338).

Wspomniany wyżej filozoficzny dystans Waldemara Kmiecikowskiego wobec badanych koncepcji można dostrzec także w innym tekście umieszczonym w trzeciej części książki. Rola uczuć w Ingardenowskiej etyce jest przecież wyrazem twórczego podejścia do rozważań Ingardena i zastosowaniem jego przemyśleń nad poznawaniem wartości estetycznych do problemu poznawania wartości moralnych. Wykorzystując między innymi koncepcję kalokagatia, a także uznanie wartości moralnych i wartości estetycznych za jakości absolutne czy związki uczuciowej głębi z wymiarem moralnym człowieka, autor studiów z dwudziestowiecznej [...] wykazuje ścisłe związki życia moralnego człowieka z jego uczuciowością. Częściowo polemizując z Ingardenem (np. wobec tezy o pierwotnej etycznej neutralności horyzontu uczuciowego), Kmiecikowski finalnie stwierdza, że Ingardenowska refleksja etyczna "de facto" przeniknięta jest motywem uczuciowości jako decydującym dla moralności [...]. Człowiek "martwy" uczuciowo nie "dotknie" Dobra (324).

\section{Zaproszenie do dalszego myślenia}

Cała książka Kmiecikowskiego jest zaproszeniem do przemyślenia wraz z nim fundamentalnych problemów człowieka. Filozoficzna wędrówka jest jedynie i aż ciągłym dążeniem do mądrości, nie dając jednak ostatecznych rozstrzygnięć. Dlatego nie można w niej ustawać, trzeba iść dalej. Cyceron powiedział: Ludzie przestaja myśleć, gdy przestaja czytać. Ponieważ myślenie, jak powiedzieliśmy wyżej, decyduje o wyjątko- 
wości człowieka w świecie, dlatego nie możemy z niego zrezygnować, a uwzględniając kryterium Cycerona, w konsekwencji nie możemy przestać czytać. Waldemar Kmiecikowski w interesujący sposób chce nas zainspirować do myślenia przez czytanie, prezentując w ostatniej części książki siedem recenzji, które wpisują się swą tematyką w całość podejmowanej problematyki. Można tutaj odnaleźć jego omówienia książek Roberta Poczobuta, Macieja Smolaka, Krzysztofa Stachewicza, Zofii Majewskiej, Bogdana Michalskiego, Czesława Porębskiego i Stanisława Ignacego Witkiewicza. W ten sposób pojawia się możliwość poznania wybranych elementów m.in. koncepcji etyki fundamentalnej Krzysztofa Stachewicza (która jest dwupiętrowa i obejmuje zarówno pułap fenomenologii moralności, jak i metafizykę moralności-s. 409), poglądów Jana Leszczyńskiego (jego idealistycznej monadologii, której towarzyszy zestaw takich pojęć jak jednostki immanentne, węzły metafizyczne czy związane treści zmysłowe - s. 394) czy refleksji z zakresu etyki biznesu Czesława Porębskiego (który dąży do wiązania przemyśleń etyki biznesu z zasadniczymi momentami etyki ogólnej - s. 401). Ostatnia część książki to także okazja poznania stosunku Waldemara Kmiecikowskiego do przemyśleń zawartych w innych publikacjach naukowych. Ów stosunek zdaje się łączyć krytycyzm autora z jego otwartością na poglądy innych filozofów (być może fragment z Desideraty, który stanowi motto ostatniej części książki nie był przypadkowy: stuchaj też tego, co mówią inni-s. 355).

Adam Adamski

Uniwersytet im. Adam Mickiewicza, Poznań e-mail: orat@amu.edu.pl 